\title{
Influence of Grain Coarsening on the Creep Parameters During the Superplastic Deformation of a Severely Friction Stir Processed Al-Zn-Mg-Cu Alloy
}

DOI:

10.1007/s11661-017-4198-3

\section{Document Version \\ Accepted author manuscript}

Link to publication record in Manchester Research Explorer

Citation for published version (APA):

Orozco-Caballero, A., Ruano, O. A., \& Carreño, F. (2017). Influence of Grain Coarsening on the Creep Parameters During the Superplastic Deformation of a Severely Friction Stir Processed Al-Zn-Mg-Cu Alloy. Metallurgical and Materials Transactions A: Physical Metallurgy and Materials Science, 1-5. https://doi.org/10.1007/s11661-0174198-3

\section{Published in:}

Metallurgical and Materials Transactions A: Physical Metallurgy and Materials Science

\section{Citing this paper}

Please note that where the full-text provided on Manchester Research Explorer is the Author Accepted Manuscript or Proof version this may differ from the final Published version. If citing, it is advised that you check and use the publisher's definitive version.

\section{General rights}

Copyright and moral rights for the publications made accessible in the Research Explorer are retained by the authors and/or other copyright owners and it is a condition of accessing publications that users recognise and abide by the legal requirements associated with these rights.

\section{Takedown policy}

If you believe that this document breaches copyright please refer to the University of Manchester's Takedown Procedures [http://man.ac.uk/04Y6Bo] or contact uml.scholarlycommunications@manchester.ac.uk providing relevant details, so we can investigate your claim.

\section{OPEN ACCESS}




\title{
Author's version (before Journal formatting)
}

Please cite as: A.Orozco-Caballero, O.A. Ruano, F. Carreño. Metellurgical and Materials Transactions A 48 (2017) 3980-3984

DOI: $10.1007 / s 11661-017-4198-3$

\section{Influence of grain coarsening on the creep parameters during the superplastic deformation of a severely friction stir processed Al-Zn- $\mathrm{Mg}-\mathrm{Cu}$ alloy}

\author{
Alberto Orozco-Caballero ${ }^{(a,+, *)}$, Oscar A. Ruano ${ }^{(a)}$, Fernando Carreño ${ }^{(a)}$ \\ (a) Department of Physical Metallurgy, CENIM-CSIC, Avda. Gregorio del Amo 8, \\ Madrid 28040, Spain \\ ${ }^{(+)}$Present address: The University of Manchester, School of Materials, MSS Tower, \\ Manchester, M13 9PL, United Kingdom. \\ * Corresponding author: Tel.: +34 915538900 ext: 217; fax: +34 915347425. \\ E-mail address: aorozcocaballero@gmail.com,aorozco@cenim.csic.es (A. Orozco- \\ Caballero)
}

\begin{abstract}
During grain boundary sliding in ultrafine-grain materials at intermediate temperatures and high strain rates $\left(\sim 10^{-2} \mathrm{~s}^{-1}\right)$ apparent creep parameters usually deviate from the theoretical values, due to microstructural coarsening. An analysis has been carried out in a severely friction stir processed (FSP) 7075 alloy with three different ultra-fine grain sizes (L), obtaining explicit grain size dependence of the creep parameters $\mathrm{n}_{\mathrm{ap}}=\mathrm{n}_{\mathrm{ap}}(\mathrm{L})$ and $\mathrm{Q}_{\mathrm{ap}}=\mathrm{Q}_{\mathrm{ap}}(\mathrm{L})$, confirming the validity of the theoretical values of these parameters in the constitutive equation.
\end{abstract}

Keywords: aluminum alloys; friction stir processing; grain boundary sliding; grain growth; creep 


\section{Main Body:}

Bulk nanostructured materials usually present good superplastic response at high strain rates and relatively low temperatures due to their exceptional microstructures in the form of highly misorientated ultrafine grains [1-6]. In this regard, friction stir processing (FSP) is a severe plastic deformation (SPD) technique based on the concepts of friction stir welding (FSW) [7] capable of producing ultrafine grain sizes $(<1 \mu \mathrm{m})$ using appropriate parameters [8-12]. The effects of FSP on the microstructure modification and further mechanical properties and formability have been extensively studied in the Al 7075 alloy [11-20].

Two deformation mechanisms usually operate at intermediate to high temperatures in fine grain materials containing precipitates and solutes, like the $\mathrm{Al}$ 7075 alloy: constant substructure slip-creep [21] and grain boundary sliding (GBS) [1]. In this study we focus on GBS, which requires fine $(\lesssim 15 \mu \mathrm{m})$, equiaxed and highly misoriented grains [22,23]. Its constitutive equation is [1]:

$$
\dot{\varepsilon}=\mathrm{K}\left(\frac{\sigma}{\mathrm{E}}\right)^{2}\left(\frac{\mathrm{b}}{\mathrm{L}}\right)^{\mathrm{p}} \exp \left(-\frac{\mathrm{Q}}{\mathrm{RT}}\right)
$$

where $\dot{\varepsilon}$ is the strain rate, $\mathrm{K}$ is a constant, $\sigma$ is the flow stress, $\mathrm{E}$ is Young's Modulus, $\mathrm{b}$ is Burgers vector modulus, $\mathrm{L}$ is the grain size, $\mathrm{p}$ is the grain size exponent, $\mathrm{Q}$ is the activation energy, $\mathrm{R}$ is the ideal gas constant and $\mathrm{T}$ is the temperature. The stress exponent is $\mathrm{n}=2$ for GBS. At approximately $0.4 \mathrm{~T}_{\mathrm{m}}<\mathrm{T}<0.6 \mathrm{~T}_{\mathrm{m}}, \mathrm{p}=3$ and $\mathrm{Q}=\mathrm{Q}_{\mathrm{GB}}$, while for $\mathrm{T}>0.6 \mathrm{~T}_{\mathrm{m}}, \mathrm{p}=2$ and $\mathrm{Q}=\mathrm{Q}_{\mathrm{L}}$ being $\mathrm{T}_{\mathrm{m}}$ the absolute melting temperature.

However, the theoretical $\mathrm{n}$ and $\mathrm{Q}$ values are not observed under certain testing conditions $[24,25]$. On one hand, fine L can lead to the occurrence of GBS at temperatures and $\dot{\varepsilon}$ over the power law breakdown $\left(\mathrm{PLB} \equiv \dot{\varepsilon} / \mathrm{D}_{\mathrm{L}}>10^{13} \mathrm{~m}^{-2}\right)[26$, showing $\mathrm{n}_{\mathrm{ap}}>2$ and $\mathrm{Q}_{\mathrm{ap}} \neq \mathrm{Q}_{\mathrm{GB}}, \mathrm{Q}_{\mathrm{L}}$ [27-31]. On the other hand, grain coarsening during the superplastic deformation alters the resulting values of the apparent creep parameters [33]. In this study, superplastic ultra-fine grained FSPed Al7075 alloy data showing non-model $\mathrm{n}_{\mathrm{ap}}$ and $\mathrm{Q}_{\mathrm{ap}}$ values are rationalized taking into account the $\mathrm{L}$ dependence of the GBS constitutive equation.

We used $3 \mathrm{~mm}$ thickness sheets of a commercial Al 7075 (5.68 wt. \% Zn, 2.51 wt. $\% \mathrm{Mg}, 1.59$ wt. $\% \mathrm{Cu}, 0.19$ wt. \% Cr, 0.19 wt. \% Fe, 0.052 wt. \% Si, 0.025 wt. \% 
Ti, 0.007 wt. \% Mn, bal. Al) aluminum alloy in the T6 temper, with average L 60 $100 \mu \mathrm{m}$ in $\mathrm{RD}$ and $\sim 10 \mu \mathrm{m}$ in TD, that were subjected to FSP as described elsewhere [11]. Three different L were obtained using different processing conditions, i.e. $\mathrm{L}(1)=1065 \mathrm{~nm}(1400 \mathrm{rpm}, 500 \mathrm{~mm} / \mathrm{min}$, conventional backing anvil), $\mathrm{L}(2)=530 \mathrm{~nm}(1000 \mathrm{rpm}, 500 \mathrm{~mm} / \mathrm{min}$, liquid nitrogen refrigerated backing anvil) and $\mathrm{L}(3)=385 \mathrm{~nm}(1000 \mathrm{rpm}, 1000 \mathrm{~mm} / \mathrm{min}$, liquid nitrogen refrigerated backing anvil). For discussion purposes, the L(2) condition has been selected as the reference material.

The high temperature, $473.15-723.15 \mathrm{~K}\left(200-450{ }^{\circ} \mathrm{C}\right)$, mechanical behavior was characterized by means of constant crosshead speed tensile tests (CCST) equivalent to an initial $\dot{\varepsilon}=10^{-2} \mathrm{~s}^{-1}$ which have been compensated to an equivalent constant $\dot{\varepsilon}$ at $10^{-2} \mathrm{~s}^{-1}$ throughout the test (constant strain rate tests, CSRT), and by strain-rate-change tensile tests (SRCT) ranging $\dot{\varepsilon}=10^{-1}-10^{-5} \mathrm{~s}^{-1}$. Since $\dot{\varepsilon}$ decreases with increasing $\varepsilon$ in CCST, the observed $\sigma$ values correspond to different $\dot{\varepsilon}$ when deforming the material, which is noticeable at the high $\varepsilon$ values usually considered in superplastic materials. In our calculations, it is crucial to use $\sigma-\varepsilon$ data keeping $\dot{\varepsilon}$ constant. Therefore, we first calculate the true $\dot{\varepsilon}\left(\dot{\varepsilon}_{\mathrm{t}}\right)$ for each deformation as $\dot{\varepsilon}_{\mathrm{t}}=\mathrm{v} /\left(1_{0}+\mathrm{d}\right)$, where $\mathrm{v}=0.065 \mathrm{~mm} / \mathrm{s}$ is the crosshead speed, $1_{0}=6.5 \mathrm{~mm}$ is the initial gauge length and $d$ is the instant displacement. Once $\dot{\varepsilon}_{\text {true }}$ is known, the CCST stress $\left(\sigma_{\mathrm{CCST}}\right)$ can be compensated by comparing Eq. [1] at two different $\dot{\varepsilon}$, assuming no change in the deformation mechanism during the test. Therefore, the compensated stress $\left(\sigma_{\text {comp }}\right)$ can be obtained using $\sigma_{\text {comp }}=\sigma_{\text {CCST }}\left(\dot{\varepsilon}_{\mathrm{i}} / \dot{\varepsilon}_{\mathrm{t}}\right)^{1 / \mathrm{n}_{\mathrm{ap}}}$, where $\dot{\varepsilon}_{\mathrm{i}}=10^{-2} \mathrm{~s}^{-1}$ is the initial $\dot{\varepsilon}$ and $\mathrm{n}_{\text {ap }}$ is the apparent stress exponent, obtained from the CSRT (see Fig. 2 description). The tests were performed using a universal Instron 1362 testing machine equipped with a four-lamp ellipsoidal furnace. Dog-bone tensile samples with $6 \times 2 \times 1.8 \mathrm{~mm}^{3}$ gage dimensions were electro-discharge machined along the traverse processing direction in such a way that the gage section is fully inside the stir zone. The topography of the samples after testing was evaluated in a Hitachi Cold FEG S-4800 microscope. Grain sizes were obtained as area values and then converted into Feret diameter using Sigma Scan Pro software in more than 400 grains. 
True stress - true strain curves at temperatures ranging 573.15 to $673.15 \mathrm{~K}$ (300 to $400{ }^{\circ} \mathrm{C}$ ) and an initial $\dot{\varepsilon}=10^{-2} \mathrm{~s}^{-1}$ for the microstructure $\mathrm{L}(2)=530 \mathrm{~nm}$ are shown in Fig. 1. The material presents low flow stresses $(\sigma)$, especially at $623.15 \mathrm{~K}\left(350{ }^{\circ} \mathrm{C}\right)$, and extraordinary elongations to failure $\left(\mathrm{e}_{\mathrm{F}}\right)$ of 450 and $507 \%$ at 573.15 and $623.15 \mathrm{~K}$ (300 and $350{ }^{\circ} \mathrm{C}$ ) respectively, pointing to GBS as the deformation controlling mechanism. Nevertheless, while at $573.15 \mathrm{~K}\left(300{ }^{\circ} \mathrm{C}\right) \sigma$ remains quite constant from $\varepsilon$ $=0.4$ to the beginning of necking, at $623.15 \mathrm{~K}\left(350{ }^{\circ} \mathrm{C}\right) \sigma$ increases during the whole plastic regime, from the yield point to the ultimate tensile strength (UTS). At 673.15 $\mathrm{K}\left(400{ }^{\circ} \mathrm{C}\right)$, a return to low $\mathrm{e}_{\mathrm{F}}$ and higher $\sigma$ is observed, pointing to slip creep as the dominant mechanism as discussed in [19] [32]. The topography after testing is also presented in Fig. 1. At $573.15-623.15 \mathrm{~K}\left(300-350{ }^{\circ} \mathrm{C}\right)$ the micrographs show the typical surface aspect of a material deforming by GBS, with equiaxed grains emerging from the sample interior. The observed $\mathrm{L}$ is $\sim 1.2$ and $\sim 1.9 \mu \mathrm{m}$ at 573.15 and $623.15 \mathrm{~K}\left(300\right.$ and $\left.350{ }^{\circ} \mathrm{C}\right)$, respectively. The microstructure at $673.15 \mathrm{~K}(400$ ${ }^{\circ} \mathrm{C}$ ) exhibits very coarse grains. This extreme coarsening leads to the change of mechanism provoking both large stress increment and ductility drop at $673.15 \mathrm{~K}$ (400 $\left.{ }^{\circ} \mathrm{C}\right)[32]$.

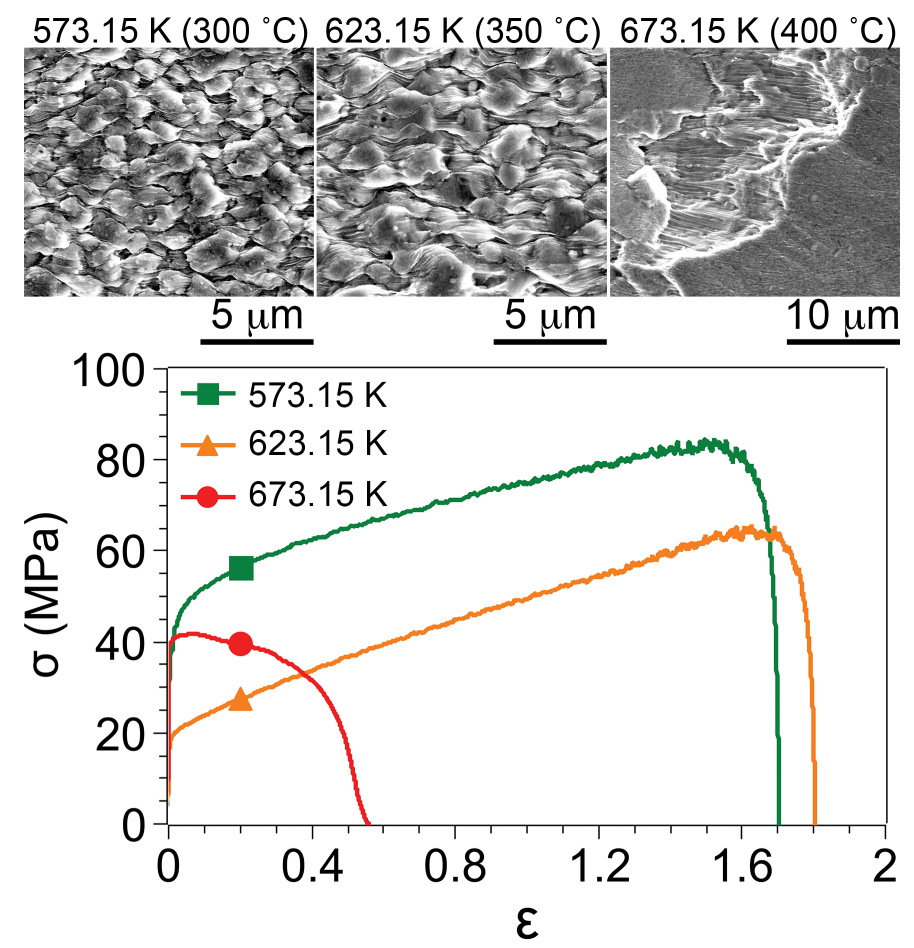

Fig. 1. True stress - true strain $(\sigma-\varepsilon)$ at a constant strain rate of $10^{-2} \mathrm{~s}^{-1}$ for the FSPed alloy with a grain size of $\mathrm{L}(2)=530 \mathrm{~nm}$ at three different testing temperatures. On the top, micrographs corresponding to the topography of the samples after testing. 
In Fig. 2, the $\dot{\varepsilon}-\sigma$ data obtained from the SRCT at 473.15-673.15 K (200-400 $\left.{ }^{\circ} \mathrm{C}\right)$ in the $\mathrm{L}(2)$ material have been normalized by the lattice self-diffusivity $\left(\mathrm{D}_{\mathrm{L}}\right)$ and the Young's modulus (E) for each temperature [33], respectively. $\mathrm{D}_{\mathrm{L}}$ was calculated by using the Arrhenius-type equation $\mathrm{D}_{\mathrm{L}}=\mathrm{D}_{0} \cdot \exp \left(-\mathrm{Q}_{\mathrm{L}} / \mathrm{RT}\right)$, using pre-exponential factor $\left(\mathrm{D}_{0}\right)$ and lattice self-diffusion activation energy $\left(\mathrm{Q}_{\mathrm{L}}\right)$ as $\mathrm{D}_{0}=1.71 \cdot 10-4 \mathrm{~m}^{-2}$ and $\mathrm{Q}_{\mathrm{L}}=142 \mathrm{~kJ} / \mathrm{mol}$ [34]. The data are compared with data from pure aluminum (open circles) [35]. A horizontal dashed line represents the PLB at $\dot{\varepsilon} / \mathrm{D}_{\mathrm{L}} \approx 10^{13} \mathrm{~m}^{-2}$ indicating roughly the upper limit for the applicability of power-law-like constitutive equations $[26,36]$. Pure aluminum $\dot{\varepsilon} / \mathrm{D}_{\mathrm{L}}-\sigma / \mathrm{E}$ data pairs below PLB are distributed along a line with a slope $\left(\mathrm{n}_{\mathrm{ap}}\right)$ about 5 , while at values of $\dot{\varepsilon} / \mathrm{D}_{\mathrm{L}}>10^{13} \mathrm{~m}^{-2}$ the values of $\mathrm{n}_{\mathrm{ap}}$ increase rapidly, being consistent with the operation of the mechanism of slipcreep with stress-dependent subgrain formation $(n \approx 5)$ [26]. It is observed in the Fig. 2 that the $\mathrm{L}(2)$ material (color filled symbols) is stronger than pure aluminum in the entire temperature range. Regarding the $\mathrm{n}_{\mathrm{ap}}$ values, at $473.15 \mathrm{~K}\left(200{ }^{\circ} \mathrm{C}\right)$ data are distributed along a high slope. The data group ranging 523.15-623.15 K $\left(250-350{ }^{\circ} \mathrm{C}\right)$ lay on a sigmoidal curve. At the highest $\dot{\varepsilon}$ at $523.15 \mathrm{~K}\left(250^{\circ} \mathrm{C}\right)$ the data fall in a line of a slope around 8 and at lower $\dot{\varepsilon}$, the slope tends to decrease to values close to 2 . Finally, at extremely low $\dot{\varepsilon}$ at 573.15 and $623.15 \mathrm{~K}\left(300\right.$ and $\left.350{ }^{\circ} \mathrm{C}\right)$, the data is again distributed along a line with a higher slope. Regarding the data set for $673.15 \mathrm{~K}$ (400 ${ }^{\circ} \mathrm{C}$ ), the material turns back to high $\sigma$ and lay on a line with slope close to 8 , aligned with the previous data for $473.15 \mathrm{~K}\left(200{ }^{\circ} \mathrm{C}\right)$. This behavior is consistent with the operation of two deformation mechanisms: i) constant substructure slip creep mechanism $(\mathrm{n} \approx 8)$ at $473.15 \mathrm{~K}\left(200{ }^{\circ} \mathrm{C}\right)$ and $673.15 \mathrm{~K}\left(400{ }^{\circ} \mathrm{C}\right)$ [21,37], and ii) GBS at $523.15-623.15 \mathrm{~K}\left(250-350{ }^{\circ} \mathrm{C}\right)$, centered at $573.15 \mathrm{~K}\left(300{ }^{\circ} \mathrm{C}\right)$ [38]. This mechanism change has been previously reported in similar severely deformed alloys [39-42], but this change is now around and above the PLB which is interesting from an industrial standpoint. 


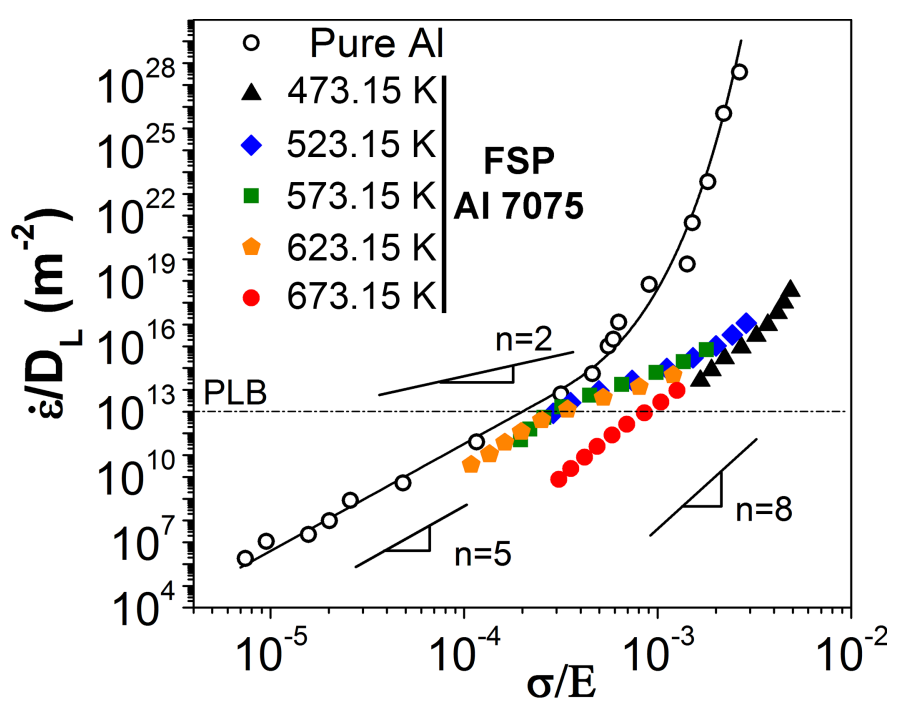

Fig. 2. $\dot{\varepsilon} / D_{L}-\sigma / E$ data pairs obtained from the strain rate changes tensile tests at different temperatures for pure aluminum (open circles, obtained from [36] ) and the processed $\mathrm{Al}$ 7075 alloy with an grain size in the stir zone after FSP of L(2) $=530 \mathrm{~nm}$ (color filled symbols).

In order to better understand the results shown in Fig. 2, we have plotted the variations of $\mathrm{n}_{\mathrm{ap}}$ and $\mathrm{Q}_{\mathrm{ap}}$ with temperature for the three FSP materials and compared with the as-received Al 7075-T6 alloy in Fig. 3. $\mathrm{n}_{\mathrm{ap}}$ and $\mathrm{Q}_{\mathrm{ap}}$ where calculated using the $\dot{\varepsilon}-\sigma$ data pairs from the SRCT by applying the corresponding equations: $\mathrm{n}_{\mathrm{ap}}=\Delta \ln \dot{\varepsilon} / \Delta \ln (\sigma / \mathrm{E})$ for each temperature and $\mathrm{Q}_{\mathrm{ap}}=\mathrm{nR}(\Delta \log (\sigma / \mathrm{E}) / \Delta(1 / \mathrm{T}))$ at $\dot{\varepsilon}=$ cte. The as-received alloy and $\mathrm{L}(1)$ present similar trends, with decreasing $\mathrm{n}_{\mathrm{ap}}$ and $\mathrm{Q}_{\mathrm{ap}}$ values when increasing the temperature. Both materials reach the minimum value of $n_{\text {ap }}$ at $723.15 \mathrm{~K}\left(450{ }^{\circ} \mathrm{C}\right)$ but, while in the case of the unprocessed alloy $n_{a p}$ is $\sim 6$, this value is 2 for the processed L(1). Regarding the $\mathrm{Q}_{\text {ap }}$ values, a similar trend is observed when increasing the temperature, when at $623.15 \mathrm{~K}\left(350{ }^{\circ} \mathrm{C}\right) \mathrm{Q}_{\mathrm{ap}}$ approaches to $\mathrm{Q}_{\mathrm{L}}$. The apparent values of both creep parameters are consistent with the operation at low temperatures of the constant substructure slip creep mechanism $(n \approx 8)$ affected by microstructural changes in the unprocessed material [21,37], changing the L(1) material to a GBS mechanism with increasing temperature. 


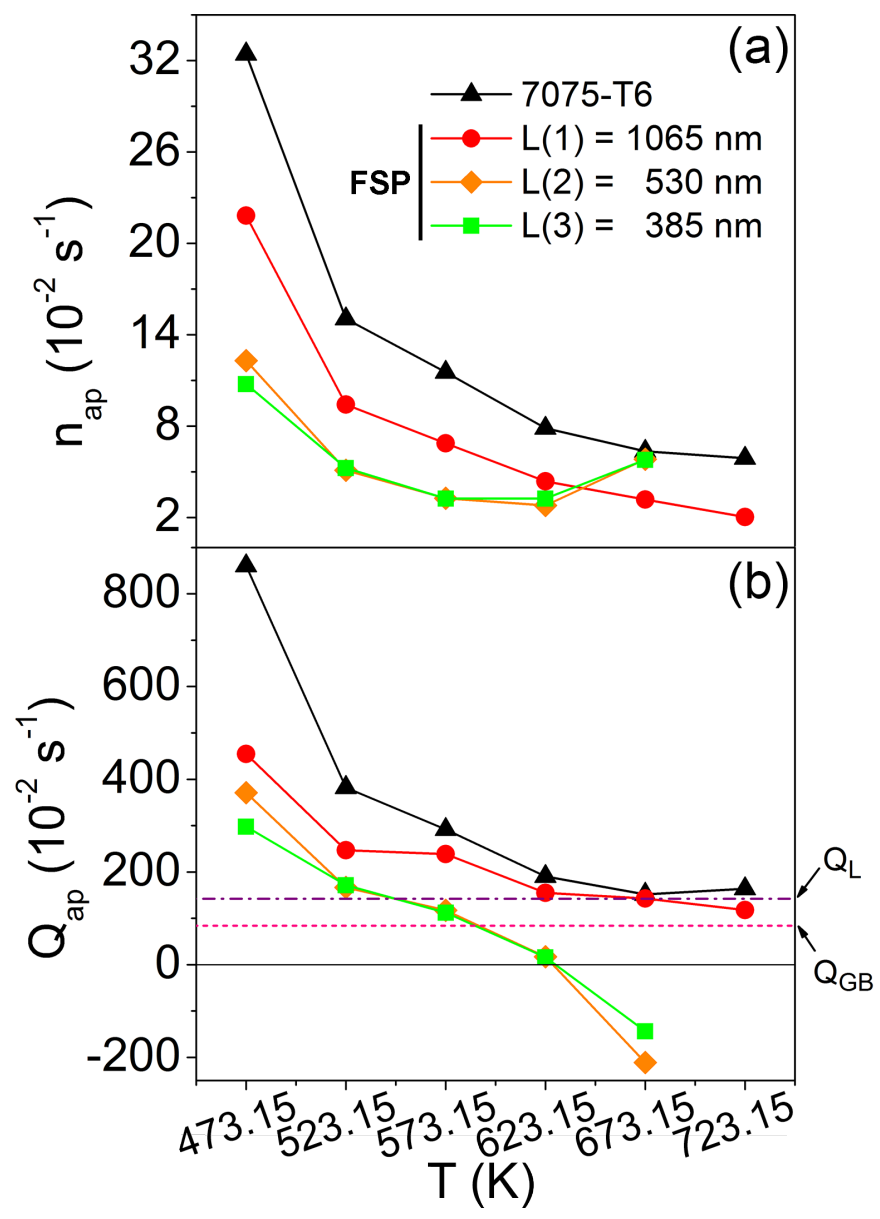

Fig. 3. Values of (a) $n_{a p}$ and (b) $Q_{a p}$ vs. testing temperature at $10^{-2} \mathrm{~s}^{-1}$ obtained from the SRCT for the starting Al 7075-T6 alloy and the FSPed alloy with three different grain sizes after processing.

On the other hand, the two finest materials in Fig. 3 follow the same behavior of decreasing $n_{a p}$ values with increasing temperature, towards $n_{a p}=2$, but close to 3 $\left(\mathrm{n}_{\mathrm{ap}}(\min )=2.8\right.$ at $\left.623.15 \mathrm{~K}\left(350^{\circ} \mathrm{C}\right)\right)$ at a temperature range of $473.15-623.15 \mathrm{~K}$ $\left(200-350{ }^{\circ} \mathrm{C}\right)$. Nevertheless, at $673.15 \mathrm{~K}\left(400{ }^{\circ} \mathrm{C}\right)$ the $\mathrm{n}_{\mathrm{ap}}$ values increase again towards $\mathrm{n}_{\mathrm{ap}}=8$. Regarding the $\mathrm{Q}_{\mathrm{ap}}$ values, a sustained decrease with increasing temperature is observed. However, three regimes can be identified. The first one from 473.15-523.15 K (200-250 $\left.{ }^{\circ} \mathrm{C}\right)$ corresponds to a strong decrease in the $\mathrm{Q}_{\mathrm{ap}}$ values, while in the 523.15 to $573.15 \mathrm{~K}\left(250\right.$ to $\left.300{ }^{\circ} \mathrm{C}\right)$ range a moderate reduction is observed with $\mathrm{Q}_{\mathrm{ap}}$ being close to $\mathrm{Q}_{\mathrm{L}}$. At $\mathrm{T}>573.15 \mathrm{~K}\left(300^{\circ} \mathrm{C}\right)$ the $\mathrm{Q}_{\mathrm{ap}}$ values decrease drastically and even negative values are observed at $673.15 \mathrm{~K}\left(400{ }^{\circ} \mathrm{C}\right)$. This unexpected behavior is related to the sudden abnormal increment of $\sigma$ from 623.15 to $673.15 \mathrm{~K}\left(350\right.$ to $\left.400^{\circ} \mathrm{C}\right)$ shown at Fig. 2. It is our contention that after the initial transition from the constant substructure slip creep mechanism $(\mathrm{n} \approx 8)$ at $473.15 \mathrm{~K}$ 
$\left(200^{\circ} \mathrm{C}\right)$ towards GBS at $523.15-623.15 \mathrm{~K}\left(250-350{ }^{\circ} \mathrm{C}\right)$, the materials suddenly change back to the initial constant substructure slip creep mechanism at higher T. Indeed, the extremely low and even negative values of $Q_{\text {ap }}$ at $\mathrm{T}>623.15 \mathrm{~K}\left(350^{\circ} \mathrm{C}\right)$ are a consequence of the change of mechanism from the "soft" GBS towards the "hard" constant substructure slip creep. Nevertheless, the $\mathrm{n}_{\mathrm{ap}}$ and $\mathrm{Q}_{\mathrm{ap}}$ values never reach the theoretical $\mathrm{n}=2$ and $\mathrm{Q}=\mathrm{Q}_{\mathrm{L}}, \mathrm{Q}_{\mathrm{GB}}$ contained in the constitutive GBS equation as observed in materials with coarser L [43-45]. However, the topography in Fig. 1 is evidence of the operation of GBS even with $n_{a p}>2$ and $Q_{a p} \neq Q_{L}, Q_{G B}$. Additionally, L dependence is observed, as corresponds to the operation of GBS.

The microstructural changes undergone during testing give rise to differences in experimental $\mathrm{n}_{\mathrm{ap}}$ and $\mathrm{Q}_{\mathrm{ap}}$ values from the theoretical ones of $\mathrm{n}=2$ and $\mathrm{Q}=\mathrm{Q}_{\mathrm{L}}, \mathrm{Q}_{\mathrm{GB}}$ and also lead to important changes in predictions by the constitutive equations, due to the L dependence of GBS (such as $L^{-p}$, being $p=2-3$ ). In fact, Fig.1 shows very high strain hardening in some temperatures, especially at $623.15 \mathrm{~K}\left(350^{\circ} \mathrm{C}\right)$. This huge difference in the flow stress from YS to UTS is related to grain coarsening during the test, which, in turn causes important changes in the values of $\mathrm{n}_{\mathrm{ap}}$ and $\mathrm{Q}_{\mathrm{ap}}$. To show this, data of SRCT and CSRT $\left(10^{-2} \mathrm{~s}^{-1}\right)$ for the $\mathrm{L}(2)$ material at $623.15 \mathrm{~K}\left(350^{\circ} \mathrm{C}\right)$ is given in Fig. 4a where the maximum $\Delta \sigma$ (UTS-YS) was observed in Fig. 1. The SRCT curve can be divided in three regions: in the first one the $\dot{\varepsilon}$ decrease in small jumps from $10^{-1}$ to $10^{-5} \mathrm{~s}^{-1}$, in the second one $\dot{\varepsilon}$ is increased again until $10^{-2} \mathrm{~s}^{-1}$ and finally in the third one $\dot{\varepsilon}$ is kept at $10^{-2} \mathrm{~s}^{-1}$ until the end of the test. Each $\dot{\varepsilon}$ is kept constant for 0.02. It can be observed that the $\sigma$ in the first $10^{-2} \mathrm{~s}^{-1}$ step for the SRCT is lower than for the CSRT at the same equivalent strain of $\varepsilon=0.45$. This is likely to be due to less grain growth since the initial $\dot{\varepsilon}$ is higher and hence it takes less time to reach the same strain level in the SRCT than in the CSRT. In Fig. $4 \mathrm{~b}$ the $\dot{\varepsilon}-\sigma$ pairs from the SCRT in Fig. $4 \mathrm{a}$ are plotted for the decreasing $\dot{\varepsilon}$ and the increasing $\dot{\varepsilon}$, showing higher $\sigma$ for the increasing $\dot{\varepsilon}$ region than the equivalents for the decreasing $\dot{\varepsilon}$ region. If the microstructure remained constant during the test, the $\sigma$ for both regions should be the same. Nevertheless, the increase in $\sigma$ during the test is indicative of grain coarsening $(\Delta \mathrm{L})$. 
(a)

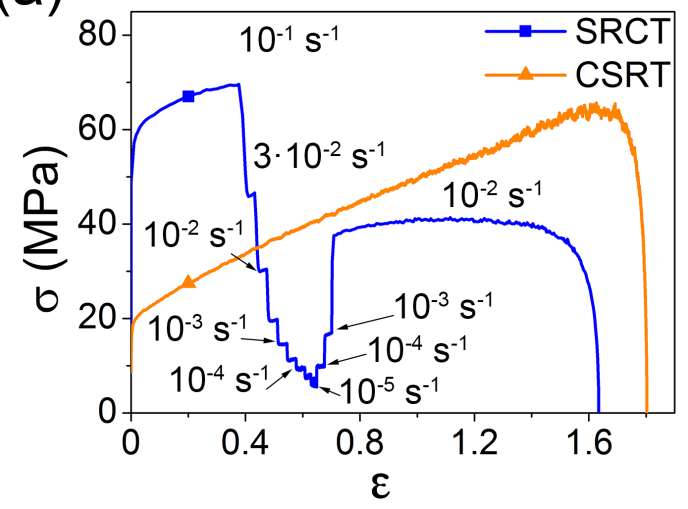

(b)

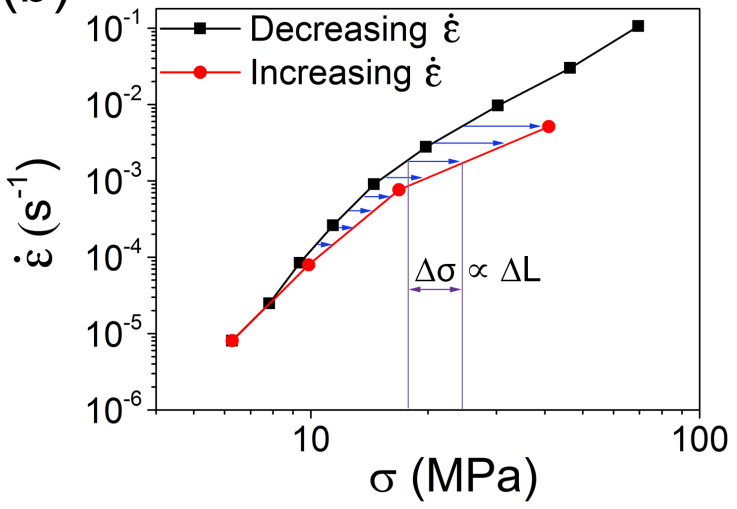

Fig. 4. (a) Comparison of the SRCT and CSRT $(\sigma-\varepsilon)$ curves at $623.15 \mathrm{~K}\left(350^{\circ} \mathrm{C}\right)$ and $(\mathbf{b})$ $\dot{\varepsilon}-\sigma$ data pairs from the SRCT test at $623.15 \mathrm{~K}\left(350^{\circ} \mathrm{C}\right)$ showing the increase in the flow stress due to the grain coarsening during the duration of the test. Both representations belongs to the FSPed alloy with a grain size $\mathrm{L}(2)=530 \mathrm{~nm}$.

These microstructural changes lead to variations in the measured $\mathrm{n}_{\text {ap }}$ and $\mathrm{Q}_{\mathrm{ap}}$ and can be related analytically [46-48]. When GBS is operative, the analytical relation for $\mathrm{n}_{\mathrm{ap}}=\mathrm{n}(\mathrm{L})$ can be derived using its definition $(\mathrm{n}=\partial \ln \dot{\varepsilon} / \partial \ln (\sigma / \mathrm{E}) \mid$ at $\mathrm{T}=$ cte $)$ and the constitutive equation (Eq. [1]) as follows:

$$
\mathrm{n}_{\mathrm{ap}}(\mathrm{L})=\mathrm{n}-\left.\left(\frac{\mathrm{p} \sigma}{\mathrm{L}}\right)\left(\frac{\mathrm{dL}}{\mathrm{d} \sigma}\right)\right|_{\mathrm{T}}
$$

being, theoretically, $\mathrm{n}=2$, and if $\mathrm{Q}=\mathrm{Q}_{\mathrm{L}}$ then $\mathrm{p}=2$ or if $\mathrm{Q}=\mathrm{Q}_{\mathrm{GB}}$ then $\mathrm{p}=3$. It is predicted that when the microstructure remains stable, $\Delta \mathrm{L}=0$, and $\mathrm{n}_{\mathrm{ap}}=\mathrm{n}=2$. Nevertheless, when the microstructure coarsens $n_{a p}>2$. Likewise, obtaining the analytical expression of $\mathrm{Q}_{\mathrm{ap}}=\mathrm{Q}(\mathrm{L})$ from its definition $((\mathrm{Q}=\mathrm{nR} \partial \log (\sigma / \mathrm{E}) / \partial(1 / \mathrm{T}) \mid$ at $\dot{\varepsilon}=$ cte)) and the constitutive equation (Eq. [1]):

$$
\mathrm{Q}_{\mathrm{ap}}(\mathrm{L})=\mathrm{Q}-\left.\left(\frac{\mathrm{pRT}^{2}}{\mathrm{~L}}\right)\left(\frac{\mathrm{dL}}{\mathrm{dT}}\right)\right|_{\dot{\varepsilon} \text { or } \frac{\sigma}{\mathrm{E}}}
$$

where, $\mathrm{p}=2$ for $\mathrm{Q}=\mathrm{Q}_{\mathrm{L}}$, or $\mathrm{p}=3$ for $\mathrm{Q}=\mathrm{Q}_{\mathrm{GB}}$. Similarly to $\mathrm{n}_{\mathrm{ap}}=\mathrm{n}(\mathrm{L})$, when the microstructure remains constant, $\mathrm{Q}_{\mathrm{ap}}=\mathrm{Q}_{\mathrm{L}}, \mathrm{Q}_{\mathrm{GB}}$, but if coarsens then $\mathrm{Q}_{\mathrm{ap}}<\mathrm{Q}_{\mathrm{L}}(\mathrm{p}=2)$, $\mathrm{Q}_{\mathrm{GB}}(\mathrm{p}=3)$.

The original equations defining $\mathrm{n}$ and $\mathrm{Q}$ are for an ideal situation of high temperature behavior in steady state. This is not often the experimental condition since grain growth takes place during deformation of a given test. As an 
approximation, we introduced Eqs. (2) and (3) for consideration of the sensitivity to grain coarsening of $\mathrm{n}$ and $\mathrm{Q}$. Therefore, it is assumed that successive steady states are obtained for increasing $\mathrm{L}$. These equations are deduced for small $\Delta \mathrm{L}$ as a function of stress and temperature for a given $\dot{\varepsilon}$. Larger increments would require integration of those equations.

However, Eq. (1) is always valid for large $\Delta \mathrm{L}$ and can be used to estimate the initial effective grain size $\left(\mathrm{L}_{\mathrm{i}}\right)$ from measurements of the final $\mathrm{L}$ assuming a GBS mechanism [49]. It has to be remembered that $\dot{\varepsilon}$ and T remains constant during the test as follows $\mathrm{L}_{\mathrm{i}}=\mathrm{L}_{\mathrm{f}} \cdot\left(\sigma_{\mathrm{i}} / \sigma_{\mathrm{f}}\right)^{\mathrm{n} / \mathrm{p}}$. It is reasonable considering $\mathrm{L}_{\mathrm{i}}$ at $\varepsilon \approx 0.1$ in Fig. 1 . At $623.15 \mathrm{~K}\left(350^{\circ} \mathrm{C}\right), \mathrm{L}_{\mathrm{f}}=1.9 \mu \mathrm{m}, \sigma_{\mathrm{i}}($ at $\varepsilon=0.1)=24 \mathrm{MPa}, \sigma_{\mathrm{f}}=\mathrm{UTS}=64 \mathrm{MPa}, \mathrm{n}=2$ and $p=2$ thus $L_{i}=0.71 \mu \mathrm{m}$, or if $p=3$ then $L_{i}=0.99 \mu \mathrm{m}$. These values are consistent with the experimental evidence and the constitutive equation for GBS, as slip creep would not predict a strengthening by microstructural coarsening. As a consequence of this large grain coarsening during the test the $\mathrm{n}_{\mathrm{ap}}$ and $\mathrm{Q}_{\mathrm{ap}}$ values differ from the theoretical ones.

In summary, the high temperature creep behavior of a severely deformed FSP 7075-T6 alloy with three different ultra-fine grain sizes $(0.38,0.53$ and $1.1 \mu \mathrm{m})$ has been rationalized. The detailed analysis of the deformation mechanism confirms that GBS is controlling deformation as evidenced by low $\sigma$, large elongations, low stress exponents and tested sample topography, in the superplastic window. However, the experimental creep parameters $\mathrm{n}_{\mathrm{ap}}$ and $\mathrm{Q}_{\mathrm{ap}}$ do not correspond to the theoretical values. This is mainly due to the microstructural changes that occur during deformation. Explicit $L$ dependence of the creep parameters $n_{a p}=n(L)$ and $Q_{a p}=Q(L)$ have been derived from the operating constitutive creep equation. Calculations of the dependence of $\mathrm{n}$ and $\mathrm{Q}$ with the changed $\mathrm{L}$ confirm the validity of the theoretical values of the constitutive equation parameters for GBS.

\section{Acknowledgments}

Financial support from Projects MAT2012-38962 and MAT2015-68919-C3-1$\mathrm{R}$ (MINECO/FEDER) is gratefully acknowledged. A. Orozco-Caballero also thanks CSIC for a JAE-Pre fellowship, co-funded by the European Social Fund. FSE 20072013. We also thank Dr David Lunt from The University of Manchester for the language review and advice. 


\section{References}

[1] O.A. Ruano and O.D. Sherby: Rev. Phys. Appliquée, 1988, vol. 23, pp. 625-37.

[2] R. Valiev: Nat. Mater., 2004, vol. 3, pp. 511-16.

[3] Yuntian T Zhu, Terry C Lowe, and Terence G Langdon: Scr. Mater., 2004, vol. 51, pp. 825-30.

[4] R. K. Islamgaliev, R. Z. Valiev, R. S. Mishra, and A. K. Mukherjee: Mater. Sci. Eng. A, 2001, vol. 304-306, pp. 206-10.

[5] R. Z. Valiev: Met. Mater. Int., vol. 7, pp. 413-20.

[6] C. M. Cepeda-Jiménez, M. Castillo-Rodríguez, J. M. Molina-Aldareguia, Y. Huang, T. G. Langdon, and M. T. Pérez-Prado: Mater. Sci. Eng. A, 2017, vol. 679, pp. 36-47.

[7] W.M. Thomas, E.D. Nicholas, J.C. Needham, M.G. Murch, P. Templesmith, and C.J. Dawes: EP0615480 B01, Aug. 1995.

[8] J.-Q. Su, T.W. Nelson, and C.J. Sterling: J. Mater. Res., 2003, vol. 18, pp. 1757-60.

[9] Z. Y. Ma and R. S. Mishra: Scr. Mater., 2005, vol. 53, pp. 75-80.

[10] J. A. del Valle, P. Rey, D. Gesto, D. Verdera, J. A. Jiménez, and O. A. Ruano: Mater. Sci. Eng. A, 2015, vol. 628, pp. 198-206.

[11] A. Orozco-Caballero, P. Hidalgo-Manrique, C. M. Cepeda-Jiménez, P. Rey, D. Verdera, O. A. Ruano, and F. Carreño: Mater. Charact., 2016, vol. 112, pp. 197-205.

[12] Jian-Qing Su, Tracy W. Nelson, and Colin J. Sterling: Scr. Mater., 2005, vol. 52, pp. $135-40$.

[13] M Conserva, M Buratti, E Di Russo, and F Gatto: Mater. Sci. Eng., 1973, vol. 11, pp. 103-12.

[14] P. Cavaliere and A. Squillace: Mater. Charact., 2005, vol. 55, pp. 136-42.

[15] L. B. Johannes and R. S. Mishra: Mater. Sci. Eng. A, 2007, vol. 464, pp. 255-60.

[16] A. Azushima, R. Kopp, A. Korhonen, D. Y. Yang, F. Micari, G. D. Lahoti, P. Groche, J. Yanagimoto, N. Tsuji, A. Rosochowski, and A. Yanagida: CIRP Ann. - Manuf. Technol., 2008, vol. 57, pp. 716-35.

[17] Y. Estrin and A. Vinogradov: Acta Mater., 2013, vol. 61, pp. 782-817.

[18] K. Wang, F. C. Liu, P. Xue, B. L. Xiao, and Z. Y. Ma: J. Mater. Sci., 2014, vol. 50, pp. 1006-15.

[19] A. Orozco-Caballero, C. M. Cepeda-Jiménez, P. Hidalgo-Manrique, P. Rey, D. Gesto, D. Verdera, O. A. Ruano, and F. Carreño: Mater. Chem. Phys., 2013, vol. 142, pp. 18285.

[20] M. Taheri-Mandarjani, A. Zarei-Hanzaki, and H. R. Abedi: Mater. Sci. Eng. A, 2015, vol. 637, pp. 107-22. 
[21] O.D. Sherby, R.H. Klundt, and A.K. Miller: Metall. Trans. A, n.d., vol. 8, pp. 843-50.

[22] O. Ruano and O. Sherby: Rev. Metal., 1983, vol. 19, pp. 261-70.

[23] A.H. Chokshi, A.K. Mukherjee, and T.G. Langdon: Mater. Sci. Eng. R Rep., 1993, vol. 10, pp. 237-74.

[24] S.-W. Lee and J.-W. Yeh: Mater. Sci. Eng. A, 2007, vol. 460-461, pp. 409-19.

[25] M.M. El Rayes, E.A. El Danaf, and M.S. Soliman: Mater. Des., 2011, vol. 32, pp. 191622.

[26] O.D. Sherby and P.M. Burke: Prog. Mater. Sci., 1968, vol. 13, pp. 323-90.

[27] K. Turba, P. Málek, E.F. Rauch, F. Robaut, and M. Cieslar: Int. J. Mater. Res., 2009, vol. 100, pp. 851-57.

[28] P. Hidalgo-Manrique, C. M. Cepeda-Jiménez, A. Orozco-Caballero, O. A. Ruano, and F. Carreño: Mater. Sci. Eng. A, 2014, vol. 606, pp. 434-42.

[29] P. Hidalgo-Manrique, A. Orozco-Caballero, C. M. Cepeda-Jiménez, O. A. Ruano, and F. Carreño: J. Mater. Sci. Technol., 2016, vol. 32, pp. 774-82.

[30] J. M. García-Infanta, A. P. Zhilyaev, A. Sharafutdinov, O. A. Ruano, and F. Carreño: J. Alloys Compd., 2009, vol. 473, pp. 163-66.

[31] C. M. Cepeda-Jiménez, J. M. García-Infanta, O. A. Ruano, and F. Carreño: J. Alloys Compd., 2011, vol. 509, pp. 9589-97.

[32] A. Orozco-Caballero, M. Álvarez-Leal, P. Hidalgo-Manrique, C Cepeda-Jiménez M., O.A. Ruano, and F. Carreño: Mater. Sci. Eng. A, 2017, vol. 680, pp. 329-37.

[33] W Köster: Z. Für Met., 1948, vol. 39, pp. 1-9.

[34] T.S. Lundy and J.F. Murdock: J. Appl. Phys., 1962, vol. 33, pp. 1671-73.

[35] D. Caillard and J.L. Martin: Rev. Phys. Appliquée, 1987, vol. 22, pp. 169-83.

[36] H. J. Frost and M. F. Ashby: Deformation Mechanism Maps: The Plasticity and Creep of Metals and Ceramics, Pergamon Press, Oxford, UK, 1982.

[37] A. Orozco-Caballero, S. K. Menon, C. M. Cepeda-Jiménez, P. Hidalgo-Manrique, T. R. McNelley, O. A. Ruano, and F. Carreño: Mater. Sci. Eng. A, 2014, vol. 612, pp. 16271.

[38] H. Lüthy, R.A. White, and O.D. Sherby: Mater. Sci. Eng., 1979, vol. 39, pp. 211-16.

[39] Z. Y Ma, R. S Mishra, and M. W Mahoney: Acta Mater., 2002, vol. 50, pp. 4419-30.

[40] R. S. Mishra and Z. Y. Ma: Mater. Sci. Eng. R Rep., 2005, vol. 50, pp. 1-78.

[41] I. Charit and R. S. Mishra: Acta Mater., 2005, vol. 53, pp. 4211-23.

[42] Z. Y. Ma, R. S. Mishra, and F. C. Liu: Mater. Sci. Eng. A, 2009, vol. 505, pp. 70-78.

[43] Y Huang, N Ridley, F. J Humphreys, and J. -Z Cui: Mater. Sci. Eng. A, 1999, vol. 266, pp. 295-302.

[44] X. Yang, H. Miura, and T. Sakai: Mater. Trans., 2002, vol. 43, pp. 2400-2407. 
[45] Y. Kwon and Y. Chang: J. Mater. Eng. Perform., n.d., vol. 10, pp. 60-65.

[46] F. Carreño and O. A. Ruano: Acta Mater., 1998, vol. 46, pp. 159-67.

[47] Fernando Carreño and Oscar A. Ruano: Metall. Mater. Trans. A, n.d., vol. 30, pp. 371-76.

[48] F. Carreno and O. A. Ruano: Rev. Metal., 2001, vol. 37, pp. 215-19.

[49] F. C. Liu and Z. Y. Ma: Mater. Sci. Eng. A, 2011, vol. 530, pp. 548-58. 